\title{
Studies on modified atmospheric packaging of banana
}

\author{
A. Venkateswarlu* AND CH. V.V. Satyanarayana
}

Department of Processing and Food Engineering, College of Agricultural Engineering, Acharya N.G. Ranga Agricultural University, BAPATLA (A.P.) INDIA

Email : angirekulavenkateswarlu@gmail.com

SUMMARY :

Banana (Musa paradisiaca) is one of the commercially important tropical fruits being produced in more than 120 countries in the world with an annual production of 88 million tons from an area of 10 million ha. MAP is a well established technology, which along with low temperature storage helps in extending the shelf-life and maintenance of the quality of fruits. A shelf-life of 25 days was observed when the banana were packed in LDPE, PP and PVC pouches and stored at $13^{\circ} \mathrm{C}$ temperatures whereas a shelf-life of 15 days was observed when the packed bananas were stored at room temperature. The shelf-life of unpacked banana stored at room temperature was only 5 days. The quality of bananas was good when packed in LDPE pouches compared to PP, PVC pouches based on the sensory and biochemical parameters. The PLW of bananas was very low, 1.84 per cent in LDPE pouches stored at $13^{\circ} \mathrm{C}$ temperature. The ascorbic acid content of banana was highest in LDPE pouches stored at $13^{\circ} \mathrm{C}$ temperature. The increase of TSS and $\mathrm{pH}$ of banana was less in LDPE pouches. It has been concluded that the banana packed in LDPE pouches under modified atmosphere packaging and stored at $13^{\circ} \mathrm{C}$ temperature give a shelf-life 25 days in comparison to only 5 days in room temperature for unpacked bananas.

KEY WORDS : Banana, Shelf-life, TSS, Quality, Modified atmosphere packaging

How to cite this paper : Venkateswarlu, A. and Satyanarayana, Ch. V.V. (2016). Studies on modified atmospheric packaging of banana. Internat. J. Proc. \& Post Harvest Technol., 7 (1) : 67-72. DOI: 10.15740/HAS/IJPPHT/ 7.1/67-72 